\title{
Evaluation and Selection of Cherry Tomato [Solanum lycopersicum (L.) var. cerasiforme Mill.] Genotypes for Growth and Yield Contributing Characters
}

\author{
E. Venkadeswaran ${ }^{1 *}$, P. Irene Vethamoni ${ }^{2}$, T. Arumugam ${ }^{1}$, \\ N. Manivannan ${ }^{3}$ and S. Harish ${ }^{4}$
}

${ }^{1}$ Department of Vegetable Crops, Horticultural College and Research Institute, Tamil Nadu Agricultural University, Coimbatore, Tamil Nadu - 641003, India

${ }^{2}$ RVS Padmavathy College of Horticulture, Sempatti, Dindigul, Tamil Nadu - 624 707, India

${ }^{3}$ National Pulses Research Centre, Vamban, Tamil Nadu - 622303, India

${ }^{4}$ Department of Plant Pathology, Agricultural College and Research Institute, Madurai,

Tamil Nadu - 625104, India

*Corresponding author

\section{Keywords}

Cherry tomato,

Cerasiforme,

Evaluation, Growth and Yield

Article Info

Accepted:

06 May 2018

Available Online:

10 June 2018

\section{A B S T R A C T}

The present study was conducted to evaluate the cherry tomato genotypes for growth and yield contributing characters under shade net conditions. Among the twenty four genotypes used, the tallest plant at final harvest was recorded by the genotype Pant Cherry Tomato $1(266.22 \mathrm{~cm})$ while, number of primary branches plant $^{-1}$ at final harvest was found to be the highest in LE 13 (16.53). The earliest days to first flowering was noted in LE 315 (26.40 days) which was followed by IIHR 2753 (27.53 days). The maximum inter nodal length of main stem was recorded by Pusa Cherry Tomato 1 (3.69) and maximum stem girth was noted in LE $13(5.64 \mathrm{~cm})$. Pusa Cherry Tomato 1 recorded the highest number of flowers cluster $^{-1}$ (51.20) while, LE 13 recorded the highest number of flowering clusters (truss) plant ${ }^{-1}$ (103.07). The highest number of fruits cluster ${ }^{-1}$ was observed in Pusa Cherry Tomato 1 (17.07) followed by Pant Cherry Tomato 1 (13.80) and LE 87 recorded the highest number of fruit cluster plant ${ }^{-1}(59.21)$. The highest per cent fruit set was noticed in IIHR 2754 (83.94 per cent) and highest number of fruits plant $^{-1}$ was recorded by the genotype Pant Cherry Tomato 1 (360.80) followed by Pusa Cherry Tomato 1 (326.70). The genotypes VGT 95, Pant Cherry Tomato 1 and Pusa Cherry Tomato 1 recorded minimum number of locules (2.00). The single fruit weight was ranged from $3.28 \mathrm{~g}$ (Pant Cherry Tomato 1) to $15.96 \mathrm{~g}$ (ATL-01-19). Pant Cherry Tomato 1 recorded the minimum number of seeds fruit $^{-1}$ (8.39) with minimum seed weight of $0.0112 \mathrm{~g}$. LE 1223 registered the highest fruit yield plant $^{-1}(1572.36 \mathrm{~g})$ and yield hectare ${ }^{-1}$ (31.45 tonnes). 


\section{Introduction}

Tomato [Solanum lycopersicum (L.)] is one of the most popular and widely grown Solanaceous fruit vegetable in the world. The most genetic diversity is found in the wild relatives of tomato, which show variability for fruit quality characteristics such as flavour, aroma, color, and texture (Miller and Tanksley, 1990). Wild germplasm has been underutilized for tomato improvement, started in 1930's and accelerating to the present time (Rick, 1986). Cherry tomato [Solanum lycopersicum (L.) var. cerasiforme Mill.] is a popular, table purpose tomato with small fruits with a bright red colour resembling a cherry and having an excellent taste (Charlo et al., 2007), which is consumed as fresh vegetable as well as raw material for processed products such as juice, ketchup, sauce, canned fruits, puree, paste and unripe green fruits are used for preparation of pickles and chutney. Cherry tomato is the probable ancestor of the cultivated tomato; its fruits are consumed more as a fruit rather than as a vegetable. The wild cherry tomato was first found throughout tropical and subtropical America and then propagated in the tropics of Asia and Africa (Gharezi et al., 2012). This is a warm season crop and required long growing periods to reap more harvests and is the most promising crop under protected structures (Vidyadhar $e t$ al., 2014). Cherry tomatoes, one of the promising wild types of Solanum, in breeding programs offers great potential because of their valuable characteristics in terms of genetic diversity for selection of parental material and their broad geographic range. The first appearance of the cherry tomato on European markets dates back to the nineteenseventies, and was the result of imports from a number of different regions, firstly the USA and later Israel and Senegal (Branca and Leonardi, 1992). Presently, cherry tomatoes are widely cultivated in Central America and are distributed in California, Korea, Germany,
Mexico and Florida (Renuka et al., 2014). About 24.00 per cent of retail sales of tomatoes in the U.S are contributed by cherry tomato. They are becoming popular in the retail chains and marketed at a premium price compared to regular tomatoes. Cherry tomato adaptation provides high possibilities for inclusion in breeding programs, using their valuable characteristics on genetic diversity for selecting parents, together with their large geographical diversity (Medina and Lobo, 2001). Thus, there is a need to increase the production and productivity of cherry tomato in the country. In order to produce high quality fruits with enhanced productivity, cherry tomato could be grown under shade houses. With this background the present investigation aimed to evaluate the cherry tomato genotypes for growth and yield traits under shade net condition.

\section{Materials and Methods}

The experiment was conducted during 201617 in the University orchard, Department of Vegetable crops, Horticultural College and Research Institute, Tamil Nadu Agricultural University, Coimbatore, Tamil Nadu. Twenty four cherry tomato genotypes were collected from various research institutes across the country viz., Indian Institute of Horticultural Research, Bengaluru (IIHR 2753, IIHR 2754, IIHR 2871, IIHR 2873 and IIHR 2876), Indian Agricultural Research Institute, New Delhi (Pusa Cherry Tomato 1), GovindBallabh Pant University of Agriculture and Technology, Pantnagar (Pant Cherry Tomato 1) and Tamil Nadu Agricultural University, Coimbatore (ATL-01-19, HAT 20, LE 13, LE 87, LE 89, LE 315, LE 338, LE 598, LE 887, LE 1223, PAV 2373, VGT 89, VGT 90, VGT 95, VR 35, VRCT 17 and VRCT 155). The experiment was laid out in a Randomized Block Design and was replicated thrice. The seeds were sown in the protrays using sterilized and enriched coco-peat as growing 
media. The main field was prepared to a fine tilth and FYM@25 t ha ${ }^{-1}$ was applied at the time of last ploughing. The cherry tomato seedlings were planted on beds in a paired row system under shade net house condition. All the other cultural practices as recommended (Crop production techniques of horticultural crops, 2013) were followed as in tomato. Observations were recorded for different traits from five plants in each replicated entry selected randomly and were tagged.

\section{Results and Discussion}

\section{Growth contributing characters}

In any crop breeding programme, it is essential to eliminate the undesirable types which can be achieved by studying the mean performance of genotypes. The mean performance of different growth traits of twenty four cherry tomato genotypes were presented in Table 1. The plant height at flowering was found to be the highest in the genotype IIHR $2753(116.09 \mathrm{~cm})$ followed by Pusa Cherry Tomato $1(114.44 \mathrm{~cm})$ and IIHR $2754(111.81 \mathrm{~cm})$. The genotype ATL-01-19 recorded the lowest plant height of $61.75 \mathrm{~cm}$ at flowering. The tallest plant at final harvest was recorded by the genotype Pant Cherry Tomato $1(266.22 \mathrm{~cm})$ followed by Pusa Cherry Tomato $1(261.86 \mathrm{~cm})$ and IIHR 2753 $(229.23 \mathrm{~cm})$. These indeterminate growth habits are mainly preferred because of their longer harvest duration Prema et al., (2011a). These results were in concurrence with the earlier findings of Nitzsche et al., (2003), Kumar et al., (2014) and Renuka et al., (2014) in cherry tomato.

The highest number of primary branches plant ${ }^{-}$ 1 at flowering was recorded by the genotype Pusa Cherry Tomato 1 (11.07) followed by LE 23 (10.67) and IIHR 2754 (10.40). The number of primary branches plant ${ }^{-1}$ at final harvest was found to be the highest in the genotype LE 13 (16.53) followed by Pusa Cherry Tomato 1 (15.00) and LE 87 (14.80). More number of branches results in more production of leaves, the size of the leaf and number of leaves which decides the efficiency of photosynthesis activity which contributed towards better growth and yield. Mahendrakar et al., (2006) and Gomathi (2008) also observed the similar results of more number of branches plant ${ }^{-1}$ in tomato. Such information on variation in number of primary branches plant $^{-1}$ was also available from the studies of Kumar et al., (2014) and Renuka et al., (2014) in cherry tomato.

A desirable genotype is one which produces more flowers in the early phase of crop growth that would enable to develop early hybrids. The genotype LE 315 registered the least number of days taken for first flowering (26.40 days) followed by IIHR 2753 (27.53 days) and LE 13 (28.53 days), while VRCT 155 was found to be late flowering with 50.60 days. Such earliness could be due to its higher capacity to make available assimilates to the apex during the sensitive phase before initiation Prema et al., (2011a).Peires (2002), Anand (2007) and Alam et al., (2014) also reported the contribution of the parents in developing tomato hybrids with earliness and these results were found to be similar to the findings of Prema et al., (2011b) and Kumar et al., (2014) in cherry tomato.

The genotype LE 315 was found to produce the first flower at the lowermost node (9.67) while, the genotype VRCT 155 produce the first flower at the uppermost node (15.13). Among the twenty four genotypes, the highest inter nodal length of main stem was recorded by the genotype Pusa Cherry Tomato 1 (3.69 $\mathrm{cm})$ followed by IIHR $2754(3.22 \mathrm{~cm})$ whereas, the genotype PAV 2373 was recorded the lowest inter nodal length of main stem (2.01). The stem girth was found to be the highest in the genotype LE $13(5.64 \mathrm{~cm})$ 
followed by LE $87(4.23 \mathrm{~cm})$ and LE 887 $(4.19 \mathrm{~cm})$ while, the genotype IIHR 2876 recorded the lowest stem girth of 2.91 .

\section{Yield contributing characters}

The mean performance of different yield traits of 24 cherry tomato genotypes was presented in Table 2. Among the genotypes, the genotype Pusa Cherry Tomato 1 recorded the highest number of flowers cluster $^{-1}(51.20)$ followed by Pant Cherry Tomato 1 (45.13) and IIHR 2753 (8.73). The lowest number of flowers cluster $^{-1}$ (4.20) was noted in the genotype

VGT 95. These results were in concurrence with the earlier findings of Reddy et al., (2013) in tomato and $\mathrm{Nu}$ et al., (1997), Prema et al., (2011a) and Kumar et al., (2014) in cherry tomato. Among these genotypes, LE 13 recorded the highest number of flowering clusters (truss) plant $^{-1}$ (103.07) followed by LE 87 (87.93) and IIHR 2753 (83.80).

Development of genotypes with more flower number cluster $^{-1}$ and more flowering cluster number plant $^{-1}$ helps to increase the yield through more fruit number plant ${ }^{-1}$. These results were in concurrence with the earlier findings of Samartha et al., (2009) and Reddy et al., (2013) in tomato and CeballosAguirreand Vallejo-Cabrera (2012) and Renuka et al., (2014) in cherry tomato.

Fruit number cluster ${ }^{-1}$ is an important yield attributing component in cherry tomato. The highest number of fruits cluster ${ }^{-1}$ was observed in Pusa Cherry Tomato 1 (17.07) followed by Pant Cherry Tomato 1 (13.80), IIHR 2753 (6.20) and LE 13 (5.40), while the least value was noted in VRCT 155 (2.93). Anand (2007), Gomathi (2008) and Mohamed et al., (2012) observed similar results with number of fruits cluster $^{-1}$ in tomato and Prema et al., (2011a) and Kumar et al., (2014) in cherry tomato.
Among the genotypes, LE 87 recorded the highest number of fruit cluster plant $^{-1}(59.21)$ followed by LE 887 (51.56) and IIHR 2754 (50.89).

The lowest number of fruit cluster plant ${ }^{-1}$ was recorded by the genotype Pusa Cherry Tomato 1 as 19.14. Ramya et al., (2016) also observed more number of fruit cluster plant ${ }^{-1}$ in cherry tomato. The least number of days (26.67) was taken for fruit set to fruit maturity by LE 13, LE 87, PAV 2373 and VRCT 17 and longest period for fruit set to fruit maturity was recorded by ATL-01-19 (32.93).

Per cent fruit set is an economically viable trait in crop like cherry tomato which ultimately decides the increase in yield. Among the 24 genotypes of cherry tomato taken for the study, the highest per cent fruit set of 83.94 per cent was noticed in IIHR 2754 followed by IIHR 2873 as 81.85 per cent. Per cent fruit set was the least in Pant Cherry Tomato 1 as 31.20 per cent followed by Pusa Cherry Tomato 1 (34.13 per cent).

The increased fruit set might be due to higher rate of anther dehiscence and higher pollen viability. Poongundranar (2001), Rai et al., (2005), Anand (2007) and Alam et al., (2014) also published supportive evidences regarding per cent fruit set in tomato and Prema et al., (2011a) in cherry tomato while, the least per cent fruit set in Pusa Cherry Tomato 1 was also observed by Vidyadhar et al., (2015).

In cherry tomato, the fruit number plant ${ }^{-1}$ is a prime character of importance which decides the economic yield of plant. The highest number of fruits plant ${ }^{-1}$ was recorded by the genotype Pant Cherry Tomato 1 (360.80) followed by Pusa Cherry Tomato 1 (326.70), IIHR 2753 (306.50), LE 87 (268.20) and IIHR 2754 (250.90). The genotype HAT 20 was recorded the least number of fruits plant ${ }^{-1}$ (73.20). 
Int.J.Curr.Microbiol.App.Sci (2018) 7(6): 1155-1165

Table.1 Per se performance of cherry tomato genotypes for growth contributing characters

\begin{tabular}{|c|c|c|c|c|c|c|c|c|}
\hline Genotypes & $\begin{array}{c}\text { Plant } \\
\text { height at } \\
\text { flowering } \\
(\mathbf{c m})\end{array}$ & $\begin{array}{l}\text { Plant } \\
\text { height } \\
\text { at final } \\
\text { harvest } \\
(\mathrm{cm})\end{array}$ & $\begin{array}{l}\text { Number of } \\
\text { primary } \\
\text { branches }^{-1} \\
\text { plant }^{-1} \text { at } \\
\text { flowering }\end{array}$ & $\begin{array}{c}\text { Number of } \\
\text { primary } \\
\text { branches } \\
\text { plant }^{-1} \text { at } \\
\text { final } \\
\text { harvest }\end{array}$ & $\begin{array}{c}\text { Days to } \\
\text { first } \\
\text { flowering }\end{array}$ & $\begin{array}{c}\text { Node at } \\
\text { which first } \\
\text { flowering } \\
\text { cluster } \\
\text { (truss) } \\
\text { appears }\end{array}$ & $\begin{array}{c}\text { Inter } \\
\text { nodal } \\
\text { length of } \\
\text { main } \\
\text { stem } \\
(\mathrm{cm})\end{array}$ & $\begin{array}{l}\text { Stem } \\
\text { girth } \\
(\mathrm{cm})\end{array}$ \\
\hline ATL-01-19 & 61.75 & 116.91 & 5.80 & 7.53 & 32.73 & 11.80 & 2.81 & 3.13 \\
\hline HAT 20 & 68.87 & 136.63 & 5.67 & 7.80 & 33.87 & 11.67 & 2.78 & 3.41 \\
\hline LE 13 & 101.99 & 209.27 & 10.67 & 16.53 & 28.53 & 10.73 & 3.19 & 5.64 \\
\hline LE 87 & 75.91 & 175.75 & 9.80 & 14.80 & 33.27 & 12.80 & 2.13 & 4.23 \\
\hline LE 89 & 83.44 & 128.17 & 10.33 & 9.33 & 29.20 & 11.13 & 2.57 & 3.36 \\
\hline LE 315 & 85.05 & 129.19 & 8.93 & 9.93 & 26.40 & 9.67 & 2.20 & 3.25 \\
\hline LE 338 & 71.01 & 122.99 & 7.13 & 8.47 & 33.27 & 12.07 & 2.21 & 3.21 \\
\hline LE 598 & 77.00 & 125.72 & 8.87 & 9.87 & 36.20 & 12.60 & 2.40 & 4.13 \\
\hline LE 887 & 77.21 & 141.03 & 9.13 & 11.27 & 38.27 & 13.53 & 2.35 & 4.19 \\
\hline LE 1223 & 90.01 & 155.86 & 9.33 & 13.07 & 36.80 & 13.33 & 2.53 & 4.01 \\
\hline PA V 2373 & 88.18 & 173.59 & 8.40 & 11.07 & 38.80 & 14.07 & 2.01 & 3.98 \\
\hline VGT 89 & 79.15 & 140.81 & 9.33 & 11.00 & 35.67 & 11.87 & 3.17 & 3.74 \\
\hline VGT 90 & 88.19 & 124.30 & 7.73 & 8.20 & 34.80 & 12.73 & 2.26 & 3.13 \\
\hline VGT 95 & 81.12 & 122.76 & 7.00 & 8.67 & 38.07 & 12.67 & 2.81 & 3.28 \\
\hline VR 35 & 68.65 & 125.96 & 6.73 & 8.27 & 43.20 & 12.87 & 2.36 & 3.25 \\
\hline VRCT 17 & 78.35 & 135.31 & 7.93 & 10.40 & 32.73 & 12.13 & 2.48 & 2.95 \\
\hline VRCT 155 & 71.91 & 228.29 & 7.53 & 11.00 & 50.60 & 15.13 & 2.37 & 3.83 \\
\hline IIHR 2753 & 116.09 & 229.23 & 8.40 & 12.27 & 27.53 & 11.40 & 2.36 & 3.21 \\
\hline IIHR 2754 & 111.81 & 201.25 & 10.40 & 14.30 & 42.80 & 13.73 & 3.22 & 3.26 \\
\hline IIHR 2871 & 83.32 & 188.14 & 7.67 & 8.47 & 39.40 & 13.33 & 2.55 & 3.05 \\
\hline IIHR 2873 & 75.62 & 142.67 & 8.07 & 9.33 & 34.27 & 12.80 & 2.73 & 2.93 \\
\hline IIHR 2876 & 81.67 & 138.64 & 7.20 & 8.87 & 42.60 & 14.40 & 2.69 & 2.91 \\
\hline $\begin{array}{l}\text { Pant Cherry } \\
\text { Tomato } 1 \\
\end{array}$ & 105.87 & 266.22 & 7.73 & 14.53 & 32.00 & 12.27 & 2.65 & 2.94 \\
\hline $\begin{array}{l}\text { Pusa Cherry } \\
\text { Tomato } 1 \\
\end{array}$ & 114.44 & 261.86 & 11.07 & 15.00 & 34.47 & 12.13 & 3.69 & 3.71 \\
\hline Mean & 84.86 & 163.36 & 8.37 & 10.83 & 35.65 & 12.54 & 2.61 & 3.53 \\
\hline SEd & 7.965 & 6.724 & 0.956 & 0.417 & 2.763 & 0.633 & 0.076 & 0.106 \\
\hline CD (0.05) & 22.640 & 19.113 & 2.718 & 1.187 & 7.855 & 1.798 & 0.215 & 0.301 \\
\hline
\end{tabular}


Int.J.Curr.Microbiol.App.Sci (2018) 7(6): 1155-1165

Table.2 Per se performance of cherry tomato genotypes for yield contributing characters

\begin{tabular}{|c|c|c|c|c|c|c|c|c|}
\hline Genotypes & $\begin{array}{c}\text { Number } \\
\text { of } \\
\text { flowers }^{-1} \\
\text { cluster }^{-1}\end{array}$ & $\begin{array}{c}\text { Number of } \\
\text { flowering } \\
\text { clusters } \\
\text { (truss) plant } \\
{ }_{1}\end{array}$ & $\begin{array}{c}\text { Numbe } \\
\text { r of } \\
\text { fruits } \\
\text { cluster } \\
1\end{array}$ & $\begin{array}{c}\text { Number } \\
\text { of fruit } \\
\text { cluster } \\
\text { plant }^{-1}\end{array}$ & $\begin{array}{c}\text { Days } \\
\text { from } \\
\text { fruit set } \\
\text { to fruit } \\
\text { maturity }\end{array}$ & $\begin{array}{c}\text { Per } \\
\text { cent } \\
\text { fruit set }\end{array}$ & $\begin{array}{l}\text { Numbe } \\
\text { r of } \\
\text { fruits } \\
\text { plant }^{-1}\end{array}$ & $\begin{array}{c}\text { Fruit } \\
\text { lengt } \\
\text { h } \\
(\mathrm{cm})\end{array}$ \\
\hline ATL-01-19 & 5.27 & 35.87 & 3.20 & 25.34 & 32.93 & 59.54 & 81.10 & 4.97 \\
\hline HAT 20 & 4.93 & 36.27 & 3.27 & 22.39 & 29.93 & 68.94 & 73.20 & 4.80 \\
\hline LE 13 & 7.20 & 103.07 & 5.40 & 38.35 & 26.67 & 75.93 & 207.10 & 3.53 \\
\hline LE 87 & 7.47 & 87.93 & 4.53 & 59.21 & 26.67 & 59.82 & 268.20 & 3.27 \\
\hline LE 89 & 5.47 & 81.80 & 3.87 & 45.56 & 27.53 & 71.96 & 176.30 & 3.76 \\
\hline LE 315 & 5.40 & 77.20 & 3.87 & 43.20 & 28.40 & 71.60 & 167.20 & 3.79 \\
\hline LE 338 & 5.47 & 68.20 & 3.80 & 36.16 & 30.20 & 68.42 & 137.40 & 3.59 \\
\hline LE 598 & 5.20 & 82.80 & 3.80 & 48.45 & 29.60 & 71.87 & 184.10 & 3.97 \\
\hline LE 887 & 4.53 & 70.47 & 3.07 & 51.56 & 31.40 & 66.21 & 158.30 & 4.27 \\
\hline LE 1223 & 6.73 & 74.40 & 4.40 & 45.02 & 28.67 & 63.42 & 198.10 & 4.40 \\
\hline PAV 2373 & 5.33 & 66.40 & 4.33 & 44.60 & 26.67 & 77.64 & 193.10 & 4.36 \\
\hline VGT 89 & 6.57 & 67.20 & 4.07 & 37.15 & 30.13 & 73.26 & 151.20 & 3.77 \\
\hline VGT 90 & 4.53 & 63.67 & 3.27 & 45.99 & 29.73 & 72.13 & 150.40 & 3.63 \\
\hline VGT 95 & 4.20 & 42.73 & 3.07 & 32.38 & 35.93 & 74.60 & 99.40 & 4.02 \\
\hline VR 35 & 4.27 & 68.27 & 3.07 & 48.44 & 29.93 & 70.35 & 148.70 & 3.99 \\
\hline VRCT 17 & 6.80 & 81.80 & 4.80 & 44.10 & 26.67 & 68.70 & 211.70 & 3.97 \\
\hline VRCT 155 & 4.47 & 69.40 & 2.93 & 25.46 & 35.60 & 67.19 & 74.60 & 5.14 \\
\hline IIHR 2753 & 8.73 & 83.80 & 6.20 & 49.44 & 29.27 & 71.78 & 306.50 & 3.76 \\
\hline IIHR 2754 & 5.80 & 78.71 & 4.93 & 50.89 & 29.60 & 83.94 & 250.90 & 3.48 \\
\hline IIHR 2871 & 5.20 & 60.60 & 4.13 & 40.94 & 30.00 & 78.21 & 169.10 & 3.77 \\
\hline IIHR 2873 & 5.13 & 54.73 & 4.07 & 37.99 & 29.40 & 81.85 & 154.60 & 3.74 \\
\hline IIHR 2876 & 5.00 & 56.60 & 3.87 & 39.07 & 30.60 & 76.08 & 151.20 & 3.53 \\
\hline $\begin{array}{l}\text { Pant Cherry } \\
\text { Tomato } 1 \\
\end{array}$ & 45.13 & 48.33 & 13.80 & 26.14 & 30.47 & 31.20 & 360.80 & 3.21 \\
\hline $\begin{array}{l}\text { Pusa Cherry } \\
\text { Tomato } 1\end{array}$ & 51.20 & 41.55 & 17.07 & 19.14 & 32.53 & 34.13 & 326.70 & 2.95 \\
\hline Mean & 9.17 & 66.74 & 4.95 & 39.87 & 29.94 & 68.28 & 183.33 & 3.90 \\
\hline SEd & 0.221 & 2.204 & 0.159 & 1.551 & 0.222 & 1.726 & 5.571 & 0.105 \\
\hline CD (0.05) & 0.629 & 6.264 & 0.452 & 4.409 & 0.630 & 4.906 & 15.835 & 0.300 \\
\hline
\end{tabular}


(Continued...)

\begin{tabular}{|c|c|c|c|c|c|c|c|c|c|}
\hline Genotypes & $\begin{array}{l}\text { Fruit } \\
\text { girth } \\
(\mathrm{cm})\end{array}$ & $\begin{array}{l}\text { Fruit } \\
\text { width } \\
\text { (cm) }\end{array}$ & $\begin{array}{c}\text { Number } \\
\text { of locules } \\
\text { fruit }^{-1}\end{array}$ & $\begin{array}{l}\text { Fruit } \\
\text { weight } \\
\text { (g) }\end{array}$ & $\begin{array}{l}\text { Number } \\
\text { of seeds } \\
\text { fruit }^{-1}\end{array}$ & $\begin{array}{l}\text { Weight } \\
\text { of seeds } \\
\text { fruit }^{-1} \\
\text { (g) }\end{array}$ & $\begin{array}{l}\text { Weight } \\
\text { of } 1000 \\
\text { seeds (g) }\end{array}$ & $\begin{array}{c}\text { Yield } \\
\text { plant }^{-1} \\
\text { (g) }\end{array}$ & $\begin{array}{c}\text { Yield } \\
\text { hectare }^{-1} \\
\text { (tonnes) }^{-1}\end{array}$ \\
\hline ATL-01-19 & 9.55 & 1.55 & 2.93 & 15.96 & 96.90 & 0.2723 & 2.81 & 1296.51 & 25.93 \\
\hline HAT 20 & 8.63 & 1.38 & 2.87 & 14.76 & 89.61 & 0.2482 & 2.77 & 1077.61 & 21.55 \\
\hline LE 13 & 7.37 & 1.17 & 2.60 & 6.29 & 94.52 & 0.1786 & 1.89 & 1300.28 & 26.00 \\
\hline LE 87 & 6.18 & 1.13 & 2.73 & 4.42 & 39.24 & 0.0852 & 2.17 & 1183.50 & 23.67 \\
\hline LE 89 & 7.40 & 1.13 & 3.00 & 6.10 & 37.04 & 0.0722 & 1.95 & 1073.92 & 21.48 \\
\hline LE 315 & 7.25 & 1.17 & 2.93 & 5.53 & 33.58 & 0.0628 & 1.87 & 926.97 & 18.54 \\
\hline LE 338 & 7.20 & 1.17 & 2.33 & 6.41 & 38.92 & 0.0767 & 1.97 & 881.25 & 17.62 \\
\hline LE 598 & 7.15 & 1.17 & 3.07 & 5.74 & 34.85 & 0.0599 & 1.72 & 1055.65 & 21.11 \\
\hline LE 887 & 8.23 & 1.23 & 2.93 & 5.98 & 36.31 & 0.0683 & 1.88 & 945.36 & 18.91 \\
\hline LE 1223 & 8.41 & 1.28 & 2.97 & 7.95 & 37.30 & 0.0724 & 1.94 & 1572.36 & 31.45 \\
\hline PAV 2373 & 8.00 & 1.24 & 2.27 & 7.68 & 46.63 & 0.0839 & 1.80 & 1483.76 & 29.68 \\
\hline VGT 89 & 7.37 & 1.18 & 2.33 & 8.92 & 36.11 & 0.0755 & 2.09 & 1350.11 & 27.00 \\
\hline VGT 90 & 6.21 & 1.11 & 3.07 & 5.17 & 31.39 & 0.0574 & 1.83 & 779.46 & 15.59 \\
\hline VGT 95 & 6.99 & 1.17 & 2.00 & 9.61 & 58.35 & 0.1365 & 2.34 & 957.14 & 19.14 \\
\hline VR 35 & 6.82 & 1.14 & 2.33 & 4.86 & 29.51 & 0.0513 & 1.74 & 723.90 & 14.48 \\
\hline VRCT 17 & 7.31 & 1.19 & 2.53 & 5.98 & 36.31 & 0.0697 & 1.92 & 1265.89 & 25.32 \\
\hline VRCT 155 & 10.05 & 3.03 & 2.80 & 15.38 & 93.38 & 0.2577 & 2.76 & 1148.01 & 22.96 \\
\hline IIHR 2753 & 7.13 & 1.01 & 2.67 & 4.40 & 27.20 & 0.0675 & 2.48 & 1348.79 & 26.97 \\
\hline IIHR 2754 & 6.21 & 0.97 & 2.27 & 4.20 & 25.55 & 0.0447 & 1.75 & 1054.03 & 21.08 \\
\hline IIHR 2871 & 6.39 & 1.11 & 2.20 & 4.13 & 25.08 & 0.0444 & 1.77 & 697.92 & 13.96 \\
\hline IIHR 2873 & 6.32 & 1.09 & 2.07 & 4.11 & 24.95 & 0.0429 & 1.72 & 634.85 & 12.70 \\
\hline IIHR 2876 & 6.11 & 1.09 & 2.33 & 4.05 & 24.59 & 0.0413 & 1.68 & 612.45 & 12.25 \\
\hline $\begin{array}{l}\text { Pant Cherry } \\
\text { Tomato } 1 \\
\end{array}$ & 5.49 & 1.12 & 2.00 & 3.28 & 8.39 & 0.0112 & 1.34 & 1183.21 & 23.67 \\
\hline $\begin{array}{l}\text { Pusa Cherry } \\
\text { Tomato } 1\end{array}$ & 5.19 & 0.98 & 2.00 & 3.71 & 10.48 & 0.0133 & 1.27 & 1213.78 & 24.28 \\
\hline Mean & 7.21 & 1.24 & 2.55 & 6.86 & 42.34 & 0.0900 & 1.98 & 1073.61 & 21.47 \\
\hline SEd & 0.248 & 0.042 & 0.091 & 0.208 & 0.712 & 0.002 & 0.027 & 44.389 & 0.888 \\
\hline CD (0.05) & 0.704 & 0.118 & 0.258 & 0.592 & 2.024 & 0.007 & 0.077 & 126.178 & 2.525 \\
\hline
\end{tabular}

Gomathi (2008) also reported that in the parental lines with more fruit number plant $^{-1}$ also contributed to developing crosses of more fruit number plant ${ }^{-1}$ which corroborated with the results of Prashanth (2003) and Mehta and Asati (2008) in tomato and Ceballos-Aguirreand Vallejo-Cabrera (2012), Kumar et al., (2014) and Ramya et al., (2016) in cherry tomato. Fruit length was found to be the highest $(5.14 \mathrm{~cm})$ in the genotype VRCT 155 followed by ATL-01-19 (4.97 cm). The least value of fruit length was recorded by Pusa Cherry Tomato $1(2.95 \mathrm{~cm})$ followed by Pant Cherry Tomato $1(3.21 \mathrm{~cm})$.Among the twenty four genotypes of the study, the genotype VRCT 155 recorded the highest fruit girth $(10.05 \mathrm{~cm})$ followed by ATL-01-19 $(9.55 \mathrm{~cm})$. The lowest fruit girth $(7.15 \mathrm{~cm})$ 
was noticed in Pusa Cherry Tomato 1 (5.19 $\mathrm{cm})$. Fruit width was found to be the highest $(3.03 \mathrm{~cm})$ in the genotype VRCT 155 followed by ATL-01-19 $(1.55 \mathrm{~cm})$. The least value of fruit width was recorded by Pusa Cherry Tomato $1(0.98 \mathrm{~cm})$. Shorter fruit length, fruit girth and fruit width of cherry tomato genotype may due to character of cerasiforme species. The present result correlates with the outcome of Kumar et al., (2014) in cherry tomato.

Tomato fruits with less locules is preferable for processing industries as it gives better firmness and indirectly better storability. Presence of limited number of locules in cherry tomato (2-3) is preferred than fruits having more locules as cherry tomato is generally preferred as table fruit vegetable. The minimum number of locules (2.00) was observed in genotypes VGT 95, Pant Cherry Tomato 1 and Pusa Cherry Tomato 1, while the maximum value for this trait was noted in LE 598 (3.07).

These results were in consonance with the findings of Kamimura et al., (1985) and Dundi and Mandalageri (1991) in tomato and Nu et al., (1997) and Renuka et al., (2014) in cherry tomato. Fruit weight is yet another important yield component that contributes directly to the yield. The single fruit weight was highest in the genotype ATL-01-19 $(15.96 \mathrm{~g})$ followed by VRCT $155(15.38 \mathrm{~g})$, HAT 20 (14.76 g), VGT 95 (9.61 g), VGT 89 (8.92 g), LE 1223 (7.95 g), PAV 2373 (7.68 g), LE 338 (6.41 g) and LE 13 (6.29 g) while it was lowest in Pant Cherry Tomato 1 (3.28 g) followed by Pusa Cherry Tomato 1 (3.71 g). Indu Rani (2002) also concluded that the parents exhibited higher per se for fruit weight in tomato. It also conformity with the findings of Macua et al., (2009), Boches et al., (2011) and Ramya et al., (2016) in cherry tomato.
A fruit with more number of seeds is a preferable trait in hybrid vegetables which could increase revenue during hybrid seed production. However in cherry tomato, lesser number of seeds fruit $^{-1}$ is preferred as it is consumed as salad. The minimum number of seeds fruit ${ }^{-1}$ (8.39) was observed in genotypes Pant Cherry Tomato 1 followed by Pusa Cherry Tomato 1 (10.48), while the maximum value for this trait was noted in ATL-01-19 (96.90) followed by LE 13 (94.52). The seed weight in cherry tomato fruit should be less, so that the fruit will have more pulp. However more number of seeds fruit $^{-1}$ will also contribute to the increase in individual fruit weight in cherry tomato.

In cherry tomato, more seed weight is not preferred as it is consumed as salad. Among the 24 genotypes of cherry tomato, the genotype Pant Cherry Tomato 1 registered the least seed weight of $0.0112 \mathrm{~g}$ followed by Pusa Cherry Tomato 1 as 0.0133 g whereas, the genotype ATL-01-19 recorded the highest seed weight fruit $^{-1}$ of $0.2723 \mathrm{~g}$ followed by VRCT 155 (0.2577 g). The 1000 seeds weight was found to be the highest in the genotype ATL-01-19 (2.81 g) followed by HAT 20 $(2.77 \mathrm{~g})$ and VRCT $155(2.76 \mathrm{~g})$. The genotype Pusa Cherry Tomato 1 recorded the lowest 1000 seeds weight of $1.27 \mathrm{~g}$ and an overall mean of $1.98 \mathrm{~g}$ was recorded for this trait. Light weight of cherry tomato seeds may be due to genetic character of the cerasiforme species (Kumar et al., 2014).

Yield is a composite character and is dependent on its constituent traits and their inheritance. Any alteration in these component traits would reflect on total yield. Selection of parents with the highest fruit yield is the primary objective in any hybrid development programme. The fruit yield plant $^{-1}$ was found to be highest in the genotype LE 1223 (1572.36 g) followed by PAV 2373 (1483.76 g), VGT 89 (1350.11 g) 
and IIHR 2753 (1348.79 g). The genotype VR 35 recorded the lowest fruit yield plant ${ }^{-1}$ of $723.90 \mathrm{~g}$. The increased yield may be due to the increased major growth and yield contributing characters under shade net house condition. The high yielding potential of any genotype will serve as the good parents for further crop improvement programme. Thus, the present result correlates with the outcome of Samadia et al., (2006), Mehta and Asati (2008), Manna and Paul (2012), Reddy et al., (2013) in tomato and Prema et al., (2011a), Silva et al., (2011), Ceballos-Aguirreand Vallejo-Cabrera (2012), Kumar et al., (2014), Renuka et al., (2014) and Ramya et al., (2016) in cherry tomato. Among the 24 genotypes of cherry tomato of the study, the genotype LE 1223 registered the highest yield hectare $^{-1}$ of 31.45 tonnes followed by PAV 2373 (29.68 tonnes) and VGT 89 (27.00 tonnes). The lowest yield hectare ${ }^{-1}$ of 12.25 tonnes was noted in IIHR 2876. These results were in agreement with the reports of Renuka et al., (2014) and Ramya et al., (2016) in cherry tomato.

Phenotypic diversity was observed among the evaluated cherry tomato genotypes for growth and yield characters, being promising in genetic breeding programs of cherry tomato. In this study, the cherry tomato genotypes LE 13, LE 87, LE 1223, VGT 89, IIHR 2753, IIHR 2754, Pant Cherry Tomato 1 and Pusa Cherry Tomato 1 are good performing for various growth and yield contributing characters taken under study. Hence, these genotypes could be better utilized for further breeding programme for the improvement of fruit yield.

\section{Acknowledgement}

The authors are highly grateful to the Department of Vegetable crops, Tamil Nadu Agricultural University, Coimbatore and University Grants Commission, New Delhi,
India for providing technical and financial assistance during the research programme.

\section{References}

Alam P.M.M, M.M. Rahman, S. Ahmad, M.A.K. Miah and M.H. Rahman. 2014. Performance of some tomato (Solanum lycopersicum L.) genotypes in summer and winter seasons. The Agriculturists, 12 (2): 64-73.

Anand, M. 2007. Studies on development of $\mathrm{F}_{1}$ hybrids for high yield and quality in tomato. (Lycopersicon esculentum Mill.). Ph.D. Thesis, Tamil Nadu Agricultural University, Coimbatore.

Boches, P., B. Peterschmidt and J.R. Myers. 2011. Evaluation of a subset of the Solanum lycopersicum var. cerasiforme core collection for horticultural quality and fruit phenolic content. HortScience, 46(11): 1450-1455.

Branca, F. and C.H. Leonardi. 1992. El comportamientodeltomatetipo "cherry" cultivadoeninvernaderofrío.

Hortofruticultura (España), 7 (8): 4852.

Ceballos-Aguirre, N. and F.A. VallejoCabrera.2012. Evaluating the fruit production and quality of cherry tomato (Solanum lycopersicum var. cerasiforme). Rev. Fac. Nal. Agr.Medellin., 65(2): 6593-6604.

Charlo, H.C.O., R. Castoldi, L.A. Ito, C. Fernandes and L.T. Braz. 2007. Production of cherry tomato under protected cultivation carried out with different types of pruning and spacing. Acta Hort., 761: 323-326.

Crop production techniques of horticultural crops. 2013. Directorate of Horticulture and Plantation Crops, Chennai and Tamil Nadu Agricultural University, Coimbatore, pp. 54-56.

Dundi, K.B. and B.B. Mandalageri. 1991. Heterosis for shelf-life and its 
components in tomato (Lycopersicon esculentum Mill.). South Indian Hort., 39: 353-355.

Gharezi, M., N. Joshi and K.M. Indiresh. 2012. Physico-chemical and sensory characteristics of different cultivars of cherry tomato. Mysore J. Agric. Sci., 46(3): 610-613.

Gomathi, S.P. 2008. Development of semi determinate $F_{1}$ hybrids in tomato (Solanum lycopersicum Mill.) with combined resistance to viral diseases and nematodes. M.Sc. Thesis, Tamil Nadu Agricultural University, Coimbatore.

Indu Rani, C. 2002. Studies on the development of $F_{1}$ hybrids in tomato (Lycopersicon esculentum Mill.) for high yield and processing qualities with resistance to root knot nematodes.Ph.D. Thesis, Tamil Nadu Agricultural University, Coimbatore.

Kamimura, S., K. Ito, H. Yoshikawa, S. Monma and T. Kanna. 1985. "Furikoma" - New tomato variety for processing. Bull. Veg. Orn. Crops Res., 5: 47.

Kumar, K., J. Trivedi, D. Sharma and S.K. Nair.2014. Evaluation for fruit production and quality of cherry tomato (Solanum lycopersicum L. var. cerasiforme). Trends in Biosciences, 7 (24): 4304-4307.

Macua, J., I. Lahoz, A. Santos, J. Zabaleta and C.F. Calvillo. 2009. Tomate de industria: variedades de tomatetipo cherry o cereza para cosechaúnica. Navarra Agraria, 172: 14-20.

Mahendrakar, P., R. Mulge, M.B. Madalageri, M.S. Patil, B.A. Ravi and K. Chandan. 2006. Exploitation of hybrid vigour for growth and yield parameters in tomato. ATSH, 33.

Manna, M. and A. Paul. 2012. Studies of genetic variability and character association of fruit quality parameters in tomato. Hort. Flora. Res. Spectrum, 1 (2): 110-116.

Medina, C.I. and M. Lobo. 2001. Variabilidadmorfológicaen el tomatepajarito (Lycopersicon esculentum var. cerasiforme), precursor deltomatecultivado. Revista Corpoica, 3 (2): 39-50.

Mehta, N. and B.S. Asati. 2008. Genetic relationship of growth and development traits with fruit yield in tomato (Lycopersicon esculentum Mill.). Karnataka Journal of Agricultural Sciences, 21 (1): 92-96.

Miller, J.C. and S.D. Tanksley. 1990. RFLP analysis of phylogenetic relationships and genetic variation in the genus Lycopersicon. Theoretical and Applied Genetics, 80 (4): 437-448.

Mohamed, S.M., E.E. Ali and T.Y. Mohamed. 2012. Study of heritability and genetic variability among different plant and fruit characters of tomato (Solanum lycopersicum L.). Int. J. Sci. \& Tech. Res., 1 (2): 55-58.

Nitzsche, P., W. Tietjen, W. Kline and S. Garrison. 2003. Evaluation of grape and cherry tomatoes in Northern New Jersey. In: Tomato varieties / trial reports - 2003. Accessed at https://njaes.rutgers.edu/

Nu, T.T., A.K. Phyo and K.S. Wai. 1997. Preliminary study on the yield and horticultural traits of cherry tomato cultivars. pp. 2-9. Accessed at http://www.google.co.in/url?sa=t\&rct=j $\& \mathrm{q}=\&$ esrc $=$ s \& source $=$ web $\& \mathrm{~cd}=1 \& \mathrm{ved}$ $=0$ ahUKEwi9udTyupTUAhWJOI8KHf HtCQAQFggkMAA\&url=http\%3A\%2F $\% 2$ Fwww.cabi.org $\% 2$ Fgara $\% 2$ Fmobile \%2FFullTextPDF\%2F2014\%2F201433 98374.pdf\&usg=AFQjCNG4lfw5krq9t Q56ulLmjDky5GKxzA.

Peires, R. 2002. Genetic improvement of tomato variety, Manik.J. Agric. Sci., 4: 199-205. 
Poongundranar, S. 2001. Evaluation of parents and hybrids of tomato (Lycopersicon esculentum Mill.) for heat tolerance. M.Sc. Thesis, Tamil Nadu Agricultural University, Coimbatore.

Prashanth, S.J. 2003. Genetic variability and divergence study in tomato (Lycopersicon esculentum Mill.). M.Sc. Thesis, University of Agricultural Science, Dharwad.

Prema, G., K.K. Indiresh and H.M. Santhosha.2011a. Evaluation of cherry tomato (Solanum lycopersicum var. cerasiforme) genotypes for growth, yield and quality traits. The Asian Journal of Horticulture, 6 (1): 181-184.

Prema, G., K.K. Indiresh and H.M. Santosha. 2011b. Studies on genetic variability in cherry tomato (Solanum lycopersicum var. cerasiforme). The Asian J. Hort., 6 (1): 207-209.

Rai, N., D.S. Yadav, K.K. Patel and R.K. Patel. 2005. Effect of position of flower cluster on yield and quality of tomato hybrids. Haryana J. Hort. Sci., 34 (3-4): 310-312.

Ramya, R., M. Ananthan and V. Krishnamoorthy. 2016. Evaluation of cherry tomato [Solanum lycopersicum L. var. cerasiforme (Dunnal) A. Gray] genotypes for yield and quality traits. Asian J. Hort., 11 (2): 329-334.

Reddy, B.R., D.S. Reddy, K. Reddaiah and N. Sunil. 2013. Studies on genetic variability, heritability and genetic advance for yield and quality traits in tomato (Solanum lycopersicum L.). Int.
J. Curr. Microbiol.App. Sci., 2 (9): 238244.

Renuka, D.M., A.T. Sadashiva, B.T. Kavita, R.C. Vijendrakumar and M.R. Hanumanthiah. 2014. Evaluation of cherry tomato lines (Solanum lycopersicum var. cerasiforme) for growth, yield and quality traits. Plant Archives, 14 (1): 151-154.

Rick, C.M. 1986. Germplasm resources in the wild tomato species. Acta Horticulturae, 190: 39-47.

Samadia, D.K., R.C. Aswani and G. Dhandar. 2006. Genetic analysis for yield components in tomato land races. Haryana J. Hort. Sci., 35 (1-2): 116119.

Silva, A.C., C. A. Costa, R.A Sampaio and E.R. Martins. 2011. Evaluation of heat tolerance cherry tomato lines under organic production system. Revista Caatinga, 24 (3): 33-40.

Vidyadhar, B., B.S. Tomar and B. Singh. 2014. Effect of truss retention and pruning of berry on seed yield and quality of cherry tomato (Solanum lycopersicum var. cerasiforme) grown under different polyhouse structures. Indian Journal of Agricultural Sciences, 84 (11): 1335-1341.

Vidyadhar, B., B.S. Tomar, B. Singh and G. Kaddi. 2015. Effect of growing conditions on growth, seed yield and quality attributes in cherry tomato (Solanum lycopersicum var. cerasiferme). Indian Journal of Agricultural Sciences, 85 (1): 114-117.

\section{How to cite this article:}

Venkadeswaran, E., P. Irene Vethamoni, T. Arumugam, N. Manivannan and Harish, S. 2018. Evaluation and Selection of Cherry Tomato [Solanum lycopersicum (L.) var. cerasiforme Mill.] Genotypes for Growth and Yield Contributing Characters. Int.J.Curr.Microbiol.App.Sci. 7(06): 1155-1165. doi: https://doi.org/10.20546/ijcmas.2018.706.137 